\title{
Evaluation of Framework Conditions Supporting Young Innovators in Central Europe ${ }^{1}$
}

Martin JANUSKA* - Adam FAIFR**

\begin{abstract}
The goal of this paper is to describe and evaluate the framework conditions for young innovators in selected countries in the Central Europe region. Young innovators - people not older than 35 with innovative ideas - represent a specific target group worthy of support in their efforts and in overcoming the issues they may face due to their age, experience, knowledge or social background when attempting to develop their innovative ideas and realize their entrepreneurial ambitions. 144 young innovators and 120 mentors were gathered in so-called Regional Innovation Labs drawing on the well-known concept of living laboratories. In this context, it was possible for them to articulate young innovators' needs and requirements concerning the initial support for the development of their potential. The result was a list of twenty key supporting services selected by focus groups, including the evaluation of availability and quality of these services in selected countries.
\end{abstract}

Keywords: key support services, young innovator support, entrepreneurship support

JEL Classification: M13, O31, O32

DOI: https://doi.org/10.31577/ekoncas.2021.04.04

\section{Introduction}

For businesses, whether large or small and medium, it is increasingly difficult to maintain their competitiveness on the basis of the prices of factors and to have to strive to produce increasingly using high share knowledge, especially innovation.

\footnotetext{
* Martin JANUSKA, University of West Bohemia, Faculty of Economics, Department of Business Administration and Management and Head of Centre of Project Activities (SPA), Univerzitní 22, 30614 Plzeň, Czech Republic; e-mail: mjanuska@ kpm.zcu.cz

** Adam FAIFR, University of West Bohemia, Faculty of Economics, Department of Business Administration and Management, Univerzitní 22, 30614 Plzeň, Czech Republic; e-mail: faifr@kpm.zcu.cz

${ }^{1}$ This paper was processed within the framework of the internal research project No. SGS2021-017 of the University of West Bohemia.
} 
The continuous innovativeness of countries enables to successfully face the global competition. For many decades (Schumpeter, 1934) it is widely recognized that entrepreneurs and young firms play a major role in innovative activities. Although some researches published in recent years outline the fact that the company life cycle not necessarily implies the innovativeness of company (Tavasolli, 2015), there is no doubt that start-ups and young companies in general keeps the substantial role in finding new business opportunities and are undoubtedly involved in technological change and economic growth by introduction of radical innovations onto market (Henderson and Clark, 1990; Baumol, 2004; Henderson, 1993; Colombelli et al., 2016; Veugelers and Schneider, 2018; Henkel, Rønde and Wagner, 2015).

Thus, the young innovators became a specific target group worthy of support in their efforts and in overcoming the issues they may face due to their age, experience, knowledge or social background when attempting to put their innovative ideas and entrepreneurial ambitions into practice.

The aim of this paper is to describe and evaluate the framework conditions for young innovators (people not older than 35 with innovative ideas - as defined in project proposal) in Central Europe regions. There are two possible definitions of what is meant by the concept of a young innovator. A broader definition considers the young innovator or innovative company (YIC) as knowledge-intensive, research-based, young and independent person or company that devotes significant resources to research and development (R\&D) and innovation (Dumont, 2017).

For the purpose of this article, the target group was more specifically defined based on the concept of Young innovators (defined in project proposal). First definition of this term originates from The Massachusetts Institute of Technology, where the term was used for the first time in 1999 in order to evaluate the most successful young innovative people in particular year. Regarding to evaluation criteria, the research targets on innovative people not older than 35 years.

First key part of research is to select services that has the most significant supporting role in innovation activities as it turned out that the most problematic circumstances involves finding the right solution for needs coming from young talents, entrepreneurs, and researchers. And also that their needs are often much different from the requests of those more experienced. So, in addition to identification of the key services, analysis of current state of art of those services within the central European countries consequently takes a part in this article.

Young innovators were invited to the so-called Regional Innovation Labs drawing on the well-known concept of living laboratories. Here it was possible for them to articulate their needs and requirements concerning initial support for the development of their potential. This resulted in developing a list of the twenty key supporting services which were placed at the centre of the project's attention. 
The key supporting services required by young innovators are listed in this article and the current state of art in project partner regions in Central Europe is described according to the comparative study.

This paper is also based on the current knowledge of factors that impact on the success of innovative companies. Specifically, young innovative enterprises.

\section{Literature Review}

Competitiveness is a feature that allows a business to succeed in competition with other operators who seek to achieve the same or very similar goals. It is relying on internal resources and organizational arrangements that allow him to operate effectively and efficiently so that he can take advantage of changes in their surroundings as opportunities for success in the competition better and before it can do its competitors (Stamm, 2005). Innovation is one of the most important factors of competitiveness. Innovations are, according to Pitra (2006), understood as a new way of using external resources of the enterprise to obtain new business opportunities, i.e. to find new ways to increase revenues from its business activities. Creating something new (the result of creativity of company) must be always focused on the customer who must be offered a higher value. Innovation may refer to products, processes, management methods and business model.

\subsection{Determinants of Innovation}

Innovation is currently still an important topic, as evidenced by the new researches published in recent years. For today's businesses, however, it is not only important to know the effects that innovation brings. It is also necessary to reveal the factors that pursue innovation and examine them from not only the micro, but also meso and macro perspectives.

One of the prerequisites that creates an innovation environment is the diffusion of information and knowledge within the company (Papazoglou and Spannos, 2018). Several researches in recent years has examined influences of ICT on innovation. Lee et al. (2016) explored common features affecting ICT innovations in research conducted in 40 countries. According to this research, building a network infrastructure has a positive impact on innovation performance in selected country. Looking at mid-environment, ICT is important factor for marketing innovations which was examined on sample of Australian companies engaged in tourism (Divisekera and Ngyuen, 2018).

Although the factor of ICT appears in researches repeatedly, it is still just a tool to speed up the flow of information or preserve information, i.e. (Papazoglou and 
Spannos, 2018). In general, the ability to acquire, store, and process the new knowledge is key factor in innovation performance (Tavasolli, 2015; Papazoglou and Spannos, 2018; Protogerou, Caloghirou and Vonortas, 2017).

The special group of companies are those not reached its maturity yet. Those company could be called young firms, eventually start-ups. Several researches has been made within these companies to study the determinants of their innovativness (Tavasolli, 2015; Protogerou, Caloghirou and Vonortas, 2017). Results can be divided into two main factors. The importance of human capital and ability of financing the innovation performance. There is no question that human capital is crucial not only for young firms and not only from the innovative point of view (Belso-Martinez, Molina-Morales and Mas-Verdu, 2013; Tavasolli, 2015; Protogerou, Caloghirou and Vonortas, 2017; Divisekera and Nguyen, 2018). However, it is not only the capital of employees but also of founders of companies, young innovators, who make key strategic decisions as well as create a climate in an enterprise that may or may not be pro-innovative (Belso-Martinez, Molina-Morales and Mas-Verdu, 2013). At the same time, it appears that more synergistic effects have decentralization (Papazoglou and Spannos, 2018), diversity (Protogerou, Caloghirou and Vonortas, 2017) and the ability to absorb incentives from the outside of organization (Tavasolli, 2015; Divisekera and Nguyen, 2018). Although gender diversity can lead to a higher number of innovations, the purely male team tends to perform more radical innovations (Protogerou, Caloghirou and Vonortas, 2017). Thus, it remains a question of whether the role of diversity is positive or not, considering that the ability of innovation does not always bring survival (Hyytinen, Pajarinen and Rouvinen, 2015). Regarding to Divisekera and Nguyen (2018), there is importance of collaboration.

This ability is also reflected in the possibilities of financing innovation. The degree of innovation is not influenced by the company's life cycle but by the ability to finance the innovation and the degree of innovation does not cause easier access for providing of subsidies (Mas-Tur and Moya, 2015). That is why there is more to innovation in large enterprises (Tavassoli, 2015).

Many studies in recent years focused on the relation of R\&D and company's performance in general, Cho et al. (2008) dealt with relation between investments in R\&D and performance in Korea, and Bond and Guceri (2016) examined this issue in UK. Bobillo Sanz and Gaite (2006) focused on competitiveness and performance of Spanish industrial firms; their thesis revealed positive relation between prosperity and research and development (hereinafter referred to as R\&D). Hall, Lotti and Mairesse (2009) explored impact of innovation and R\&D on productivity of small-sized and medium-sized companies in Italy. They found a positive impact of innovation on firm's productivity, especially process innovation. 
As it turns out, the ability to obtain the necessary resources enables the company to further develop. KIS plays a role in this, whether private or public. However, raising funds from multiple sources, helping to eliminate the shortcomings of individual sources (Belso-Martinez, Molina-Morales and Mas-Verdu, 2013).

\subsection{Support Policies for Young Innovators}

The most problematic circumstances involve finding the right solution for needs coming from the side of those young talents, entrepreneurs, and researchers. Their needs are quite different from the requests of those more experienced. At the same time, services covering these needs can have different effects on young innovative companies.

The starting point for increasing the chances for survival of young businesses can be the gain of external knowledge, both from the point of view of experience and innovation-positive climate (van Weel, van Rijnsoever and Nauta, 2017; Ballon, van Hoed and Schuurman, 2018). In connection with the acquisition of physical and knowledge base new entrepreneurial incubators began to emerge since 1959 (Lewis, 2002).

The basic definition of this concept has been preserved throughout the development. But Bruneel et al. (2012) derives three significant development periods, while the recent period accents importance of ICT companies. In relation with these changes, the characteristics of the companies that use the incubator services are changing as well (Bruneel et al., 2012).

Together with business incubators, current entrepreneurship policies comprise the participation with other types of instrastructure - universities, technologic centres and living labs (Roig-Tierno et al., 2015; Nystrom et al., 2014). The main objective of the living lab concept is to support the innovative process and creativity of young entrepreneurs by fulfilling the role of intermediaries between businesses and the public sector (Mergel, 2015). When defining what living labs are, then setting and environment that support open innovation (Schaffers and Turkama, 2012).

An integral part of the innovation process that covers the various levels of entrepreneurship policies is, of course, young businesses and their needs. Ballon, van Hoed and Schuurman (2018) identified three main groups of motivations for why young businesses enter living labs. It is "a view from the outside", it means to incorporate the external viewpoints of users and stakeholders into innovation process. This kind of cooperation provides more sophisticated innovation process with deeper insights into own businesses. Compared with the tenants of business incubators considering physical facility as the most important. Gaining new knowledge, especially business knowledge, is rated as the second most important factor (van Weel, van Rijnsoever and Nauta, 2017). 
Success of entrepreneurship policies can be evaluated from the different perspectives. The basic assumption is whether engagement in these organizations yields demanded results. As it turns out, evaluating the performance of young projects entails some specificities (Lerner, 2010). The problem appears in relation to exit policy which is not always clearly stated. It has its consequences when evaluating the performance of those projects (Bruneel et al., 2012).

\subsection{Innovation Conditions in Central Europe}

The selected group of partner regions offers a relatively heterogeneous group of countries in the wider Central Europe, which differ in their maturity and innovation policies (Prokop, Stejskal and Kuvikova, 2017). In recent years, only a few articles have been published to address the innovation of businesses in the countries concerned. And studies with miscellaneous findings. The researches primarily focused on the public subsidies of the countries concerned and their impact on the innovativeness of companies in selected country.

Bronzini and Piselli (2016) examined the effects of public subsidies on business innovation in northern Italy, next to Hottenrott and Lopes-Bento (2014) examining in Germany. Both studies concluded that public subsidies increase the likelihood of innovation growth in the mentioned countries. However, some researches of recent years exploring multiple countries at once, comes from different results. For example, research by Stanek, Kvasnicka and Krcal (2018) examined the results for the Czech Republic, Germany, Bulgaria and Portugal at the same time. Whereas in the Czech Republic and Germany a positive effect of public investment on innovative business activity was found. In Bulgaria and Portugal this effect has not been demonstrated.

Some explanation is provided by Prokop, Stejskal and Kuvikova (2017), which examined key innovation factories in the Czech Republic, Slovakia or Hungary. Although the positive effect of public investment on business innovativeness was again partially confirmed, the overall business innovativeness in the country itself was related to the general environment in that country and to the general attitude towards innovation as well as to specific need of each company.

This study aims to identify and evaluate these factors (services).

\subsection{Concept of Living Labs}

The Regional Innovation lab (RIL), drawing on the well-known concept of living labs, was established within the first reporting period of the project as a key tool for direct incorporation of the young innovators in the project implementation. According to several authors (Bergvall-Kåreborn et al., 2007; Følstad, 2008; Mirijamdotter, Somerville and Holst, 2006), basically, an RIL is a body where young 
innovators are given the space to identify key supporting services and to shape other project outputs. The participation of young innovators in the RILs assures that the bottom-up approach is applied when looking for the key supporting services and when defining their required quality (Ståhlbröst, 2011).

While the positive effect of living laboratories on innovation is evident, e.g. Howells (2006). Still, there is the question of effect of participating in living lab on business sustainability. According to the available results (Ballon, van Hoed and Schuurman, 2018), living labs, in terms of return on investment, add value. At the same time, according to the latest results (Rauter et al., 2018) participation in this kind of organizations can, in addition to gaining new knowledge, overcome market failures, considering that involvement in more such infrastructures can enhance synergy effects (Roig-Tierno et al., 2015). Each Regional Innovation Lab is working in a different environment, and success will depend on the intensity and quality of relationships between entities (Dawson et al., 2015).

\section{Methodology and Data}

Young Innovators are targeted as they are considered one of the key driving forces for development of a knowledge-based economy in any region and bring to regions the high value of innovation potentials.

This paper attempts to answer the core underlying research questions:

- What are the key supporting services required by young innovators?

- How are the needs of young innovators covered by the existing supporting services?

- How many of the twenty key services are present in the regions?

- What is the quality of these services and what is the variety and quality of their providers?

- To what extent do the existing services coincide with the young innovators' needs?

This research is based on the concept of exploratory sequential research. This strategy is one of the methods of mixed research (Creswell and Clark, 2017).

First qualitative phase is devoted to identification of twenty key innovation services, as the main goal of research is to explore the current state of art within the innovation policies in partner regions. Then, each identified service is evaluated in selected regions. Both phases of research are processed in cooperation with partner organizations in selected regions.

This article relies on InoPlace project results as well as author's (Dr. Martin Januška) experience concurrently gained during participation in the InoPlace Project in years $2007-2013$. 


\subsection{Establishment of Living Labs}

According to the project documentation (Project Management Handbook, 2012), the Regional Innovation lab (RIL), drawing on the well-known concept of living labs, was established within the first reporting period of the research project as a key tool for direct incorporation of the young innovators in the project implementation. Each RIL in partners' regions must have at least 20 members, of which 18 are the young innovators themselves and two of them are the project managers. In the project covered in this research, there were a total of 144 young innovators and 120 mentors.

For the purpose of project, young innovators are defined by the following criteria:

- age: under 35,

- innovativeness: technologists, innovative entrepreneurs, scientists = in general, innovative idea holders with a willingness to make use of these ideas.

Selected partners of project should incorporate the experience and information gained into the Transnational Action Plan for improvement of services (InoPlace, 2014c), mainly based on good practice transfer (each partner should implement one pilot of good practice transfer).

The limitation of this research is the nescience of the total number of respondents corresponding to the defined characteristics in the selected regions. Therefore, the research is not supported by relevant statistical analysis and has exploratory nature. Only respondents who were involved in regional Living Labs were involved in the research.

\subsection{Regional Advisory Group}

A regional advisory group (RAG) was established in each partner region comprising the representatives of the regional innovation system. Each RAG was supposed to have 15 members recruited from different environments (service providers, public administration bodies, policy decision makers, universities, etc.).

RAGs were responsible for mapping of the state of the art of services in terms of availability and quality in each region and for the benchmarking of the regions. By following the RAGs' recommendations, it was also assured that the project activities were set into the broader regional context and went along with the regional development strategy.

The existence and operation of RAGs also provided the partners with efficient support from within the quite broad institutional framework represented in the groups. 


\subsection{Key Supporting Services}

Semi-structured interviews were used as the research method for the data collection after the formation of living labs. Members of regional innovation labs (RILs) were interviewed using a questionnaire prepared on the basis of the methodology IPMA (Doležal, Máchal and Lacko, 2012) for gathering the data. The following publications regarding research methodology were used in questionnaire preparation: (Creswell and Clark, 2017).

The selection of the twenty key supporting services followed the establishment of the Regional Innovation Labs in the partner regions and the elaboration of a long list comprising a variety of almost sixty already existing services and ideas of services which might be helpful for young innovators. The long list of services was elaborated based on literature reviews (i.e. Kaufmann and Tödtling, 2002; Sternberg, 2014; Yusuf, 2010) insights of the Regional Innovation Labs members, group discussions and brainstorming among project partners.

The final key services list was selected by focus group voting, leaving only twenty services deemed the most important and most attractive. The number of occurrences of a similar requested service was selected as the main quantitative unit. Two sources were used for creating the list of key supporting services. One was the questionnaire where all desired services were documented.

List of 20 key supporting services is represented in Table 1 while the brief description of characteristics of services is provided as well.

T a ble 1

Twenty Key Innovation Services

\begin{tabular}{|l|l|}
\hline Key supporting service & \multicolumn{1}{c|}{ Short description } \\
\hline $\begin{array}{l}\text { Capitalization and commercialization } \\
\text { of the results of R\&D }\end{array}$ & $\begin{array}{l}\text { Consultancy services - advisory on the issue of capitalization } \\
\text { of R\&D results; commercialization of innovative technologies. }\end{array}$ \\
\hline Business angels and venture capital & $\begin{array}{l}\text { Intermediary services to provide young innovators with access } \\
\text { to capital for a business start-up either in the form of business } \\
\text { angels or venture capital. }\end{array}$ \\
\hline $\begin{array}{l}\text { Support of project development } \\
\text { and applications for funds }\end{array}$ & $\begin{array}{l}\text { To support the implementation process of the project idea, to find } \\
\text { a suitable call for proposals and to help elaborate and submit } \\
\text { a good-quality proposal. }\end{array}$ \\
\hline $\begin{array}{l}\text { Support in finding investors } \\
\text { from industry and enterprises }\end{array}$ & $\begin{array}{l}\text { The objective of the service is the preparation of a young } \\
\text { innovator's enterprise for M\&A (Mergers and Acquisitions) } \\
\text { with a strategic or financial investor (expect venue capital). }\end{array}$ \\
\hline $\begin{array}{l}\text { Access of young innovators } \\
\text { to technological parks and other } \\
\text { R\&D premises }\end{array}$ & $\begin{array}{l}\text { Assistance to young innovators by providing access to technological } \\
\text { parks and other R\&D premises. }\end{array}$ \\
\hline Matchmaking platform & $\begin{array}{l}\text { The need of a universal platform, which will be a place } \\
\text { for exchanging contacts, networking, collaboration, providing } \\
\text { communication between stakeholders such as young innovators, } \\
\text { sponsors or more experienced partners. }\end{array}$ \\
\hline $\begin{array}{l}\text { First contact and information point } \\
\text { for young innovators }\end{array}$ & $\begin{array}{l}\text { The first contact with a young innovator an information point } \\
\text { which provide information about the possibilities of obtaining } \\
\text { external capital, potential business partners, supportive activities } \\
\text { and programmes and good practices. }\end{array}$ \\
\hline
\end{tabular}




\begin{tabular}{|c|c|}
\hline Public relations & $\begin{array}{l}\text { PR services for innovative start-up companies, including } \\
\text { development of PR strategy, concrete proposals for PR actions, } \\
\text { consultancy in marketing and popularization of innovative ideas. }\end{array}$ \\
\hline Business plan & $\begin{array}{l}\text { A business plan will be drafted for and in cooperation with young } \\
\text { innovators. }\end{array}$ \\
\hline Incubation and networking & $\begin{array}{l}\text { Location and services for companies planning to set themselves up } \\
\text { in business and looking for low-cost premises, facilities, services } \\
\text { and a network of opportunities and contacts. }\end{array}$ \\
\hline $\begin{array}{l}\text { Contact person for young innovators } \\
\text { in R\&D institutions }\end{array}$ & $\begin{array}{l}\text { Appointment of a contact person for young innovators in R\&D } \\
\text { institutions. }\end{array}$ \\
\hline $\begin{array}{l}\text { Intellectual property: generation, } \\
\text { commercialization and protection }\end{array}$ & $\begin{array}{l}\text { Advice on intellectual property generation and protection, patent } \\
\text { application and protection. Advice on the rules and processes } \\
\text { related to application for IP registration and commercialization, } \\
\text { IP management, legal obligations and responsibilities. }\end{array}$ \\
\hline Business start-up & $\begin{array}{l}\text { The service will provide young innovators with support during } \\
\text { the administrative and organizational setting-up of a business. } \\
\text { Mainly it will focus on advice related to formal and legal aspects } \\
\text { of the process. }\end{array}$ \\
\hline $\begin{array}{l}\text { Assistance in the commercialization } \\
\text { process }\end{array}$ & $\begin{array}{l}\text { Searching for business partners who would promote } \\
\text { the commercialization process. The service is based on the needs } \\
\text { of individual would-be entrepreneurs or entrepreneurs who need } \\
\text { help with commercialization of new products. }\end{array}$ \\
\hline $\begin{array}{l}\text { Partner search and acquisition } \\
\text { for joint projects }\end{array}$ & $\begin{array}{l}\text { Assistance with a search for suitable partners for joint projects } \\
\text { and businesses, development of a database, executive search } \\
\text { for partners upon a young innovator's request. }\end{array}$ \\
\hline Technology transfer & $\begin{array}{l}\text { Support for planning technological innovation processes; identifying } \\
\text { experts in analyzing and developing technological innovation } \\
\text { projects; making technological reviews, assistance with transfer } \\
\text { of results of scientific research activities into practice. }\end{array}$ \\
\hline Creative Hub & $\begin{array}{l}\text { A center for the future of work and the up-and-coming professions; } \\
\text { a "spinner" to enhance the university and higher education system; } \\
\text { and services to support start-ups and consolidation of creative } \\
\text { companies, with services and spaces for the incubation and } \\
\text { pre-incubation of creative experimentation workshops and enterprises. }\end{array}$ \\
\hline $\begin{array}{l}\text { Contact point for European } \\
\text { and other public funds }\end{array}$ & $\begin{array}{l}\text { Technical assistance for fund-raising using European and other } \\
\text { public funding schemes. The service would involve an analysis } \\
\text { of the funding opportunities for specific ideas of young innovators. }\end{array}$ \\
\hline $\begin{array}{l}\text { Personalized training for young } \\
\text { innovators and their companies }\end{array}$ & $\begin{array}{l}\text { Analysis of training needs, training, learning and development } \\
\text { activities, counseling on education and training for start-up companies, } \\
\text { elaboration of training and educational plans in accordance with } \\
\text { company needs and drafting target-oriented proposals for potential } \\
\text { suppliers of the training/educational courses. }\end{array}$ \\
\hline Networking conferences & $\begin{array}{l}\text { Connecting the different professionals in order to boost entrepre- } \\
\text { neurship activities. For instance, technically oriented students } \\
\text { can provide innovative ideas and their technical specifications. } \\
\text { On the other hand, such students (or young people) are not skilled } \\
\text { in business activities (e.g. management, marketing, promotion, } \\
\text { finance) and are often unable to develop a business model which } \\
\text { would work (sometimes not even to write a business plan). With } \\
\text { the organization of such conferences, students who would like to start } \\
\text { on the entrepreneurship path would meet the complementary experts } \\
\text { with whom they could connect and jointly start a new business. }\end{array}$ \\
\hline
\end{tabular}

Source: Good Practice Compendium (InoPlaCe, 2014b).

\subsection{Evaluation of Services among Regions}

The comparative study is the result of a benchmarking process that actively involved all InoPlaCe project partners from the eight regions participating in the Central Europe Programme (InoPlaCe, 2014b). 
By agreeing on a common methodology for gathering regional data, the partnership tried to ensure the highest possible level of objectivity of the inputs to the comparative analysis. There are a number of publications dealing with benchmarking of such services, for example Caiazza (2014) or Bruneel et al. (2012).

For the evaluation of each service among regions a focus groups of RAG members were processed. The focus group method is described, for instance, by (Lamb, 2012; Mazza and Berre, 2007; Gray, 2009). In the case of this research, there was a discussion by RAGs members with respondents and studies on other current projects.

Each service was evaluated by the relevant RAG regional members with a rating from 0 to 10 for each of following characteristics:

- visibility;

- availability of space;

- affordability;

- number of users of the service in the region;

- practical impact of the service;

- interrelation to other key supporting services;

- extent to which the service matches the description in the final list of services.

The overall rating of each service in each region is then given by the sum of the scores of the individual characteristics. Therefore, the minimum score of service in given region is 0 (the service is absolutely inadequate in the monitored characteristic) and the maximum score is 70 (the service is excellent in every characteristic).

\subsection{Selected Characteristics of Services}

Based on the benchmarking results in the previous section, it will be also possible to analyze individual partner regions in terms of service quality in each characteristic.

This section does not serve for the evaluation of individual services, but for the overall evaluation of 7 defined characteristics (see previous chapter). This section will help to identify the systemic weaknesses of the areas in the provision of support services.

In terms of interpretation, it will help to improve individual aspects in the regions, regardless of the specific needs of young innovators in those areas.

The evaluation will use the results of the previous section, where the evaluation of the characteristic is defined by the average evaluation of the aspect. The minimum score is 0 (the characteristic was evaluated as totally insufficient for each of the 20 services) and the maximum score is 10 (the characteristic was rated excellent for each of the 20 services). 


\section{Results}

The findings were summarized for each region. Thus, it is easy to find in the study how the InoPlaCe regions are doing in terms of availability and quality of the twenty key supporting services. These two features (availability and quality) of the selected supporting services for young innovators are depicted for the Central Europe Programme area represented by the partner regions and serve as the basis for further consideration and the formulation of remedial actions.

The twenty key supporting services are at the core of the project's efforts to improve the conditions for young innovators, since the main aim of the project is to improve the access of young innovators to these key services and to improve the services themselves to serve the needs of young innovators better. After identification and definition of key services in first stage, the matrix and methodology for data collection was created to provide information about what services of what quality and by which business supporting actors are provided in partner regions. The result of the research stage was a map showing to what extent the reality matches and fits young innovators' needs and highlighting good transferable practices. Project partners should incorporate the experience and information gained into the Transnational Action Plan for improvement of services, mainly based on good practice transfer (each partner should implement one pilot of good practice transfer) (InoPlace, 2014c).

\subsection{Comparative Study}

The present comparative study aims at providing a clear picture how the needs of young innovators are currently covered in different regions in relation to the pre-defined twenty key supporting services.

In each region, only the three providers with the highest average scores for each key service were taken into consideration for comparison among regions, because if there are three providers in a region at an excellent level and others of lower quality, the fact that the region scores as excellent is by no means affected since the young innovators have the service available at a high level of excellence.

By assigning scores, it is possible to evaluate the quality of the delivery of services in each region. The quality of each service evaluates the descending scale that ranges from 70 to 0 . Table 2 shows the evaluation of individual service in the region. Gray boxes mean that the service is absent in the region.

For further analysis the results were transformed onto qualitative scale. The services in the relevant region scoring worse than 35 are considered insufficient, scores up to 60 are deemed satisfactory, and scores over 60 are considered excellent. The Figure 1 represents the absolute frequency of services with defined qualitative characteristic. 
Table 2

Scores per Key Service/Region

\begin{tabular}{|c|c|c|c|c|c|c|c|c|}
\hline & 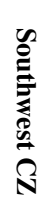 & 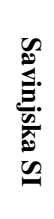 & 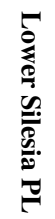 & 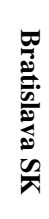 & 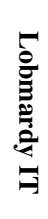 & 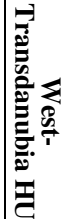 & 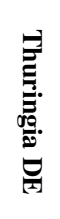 & 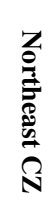 \\
\hline Capitalization and commercialization of the results of $R \& D$ & 42 & 33 & 42 & 49 & 47 & 35 & 48 & 34 \\
\hline Business angels and venture capital & & & 33 & 62 & 39 & 38 & 41 & 49 \\
\hline Support of project development and applications for funds & 46 & 43 & 44 & 43 & 40 & 37 & 46 & 52 \\
\hline Support in finding investors from industry and enterprises & & & & 59 & 41 & 34 & 47 & 50 \\
\hline $\begin{array}{l}\text { Access of young innovators to technological parks and other } \\
\text { R\&D premises }\end{array}$ & 35 & 47 & 30 & 44 & 40 & 26 & 51 & 32 \\
\hline Matchmaking platform & 51 & & 31 & 34 & 46 & 32 & 55 & 52 \\
\hline First contact and information point for young innovators & 54 & & 65 & 69 & 63 & 37 & 55 & 67 \\
\hline PR & & & & & & 35 & 47 & 37 \\
\hline Business plan & 43 & 42 & 45 & 48 & 36 & 35 & 43 & 35 \\
\hline Incubation and networking & 44 & 49 & 49 & 50 & 48 & 46 & 47 & 37 \\
\hline Contact person for young innovators in $R \& D$ institutions & & 36 & 41 & 42 & 48 & 38 & 37 & 37 \\
\hline $\begin{array}{l}\text { Intellectual property: generation, commercialization } \\
\text { and protection }\end{array}$ & 49 & 37 & 38 & 40 & 47 & 38 & 37 & 38 \\
\hline Business start-up & & 39 & 49 & 51 & 46 & 36 & 50 & 36 \\
\hline Assistance in commercialization process & 42 & & 38 & 38 & & 49 & 35 & 38 \\
\hline Partner search and acquisition for joint projects & 47 & 35 & 29 & 41 & 53 & 36 & 34 & 53 \\
\hline Technology transfer & 38 & 34 & 39 & 45 & 42 & 29 & 49 & 33 \\
\hline Creative Hub & & & 32 & 63 & 48 & 26 & 43 & \\
\hline Contact point for European and other public funds & 47 & 37 & 50 & 37 & & 25 & 38 & 53 \\
\hline $\begin{array}{l}\text { Personalized training for young innovators and their } \\
\text { companies }\end{array}$ & 38 & & 35 & 26 & 42 & 36 & 53 & 38 \\
\hline Networking conferences & & 46 & 33 & 29 & 28 & 35 & 42 & 46 \\
\hline Average & 44 & 40 & 40 & 46 & 44 & 35 & 45 & 43 \\
\hline
\end{tabular}

Source: InoPlaCe Comparative Study (2014a).

Figure 1

\section{Quality of Services in InoPlaCe Regions}

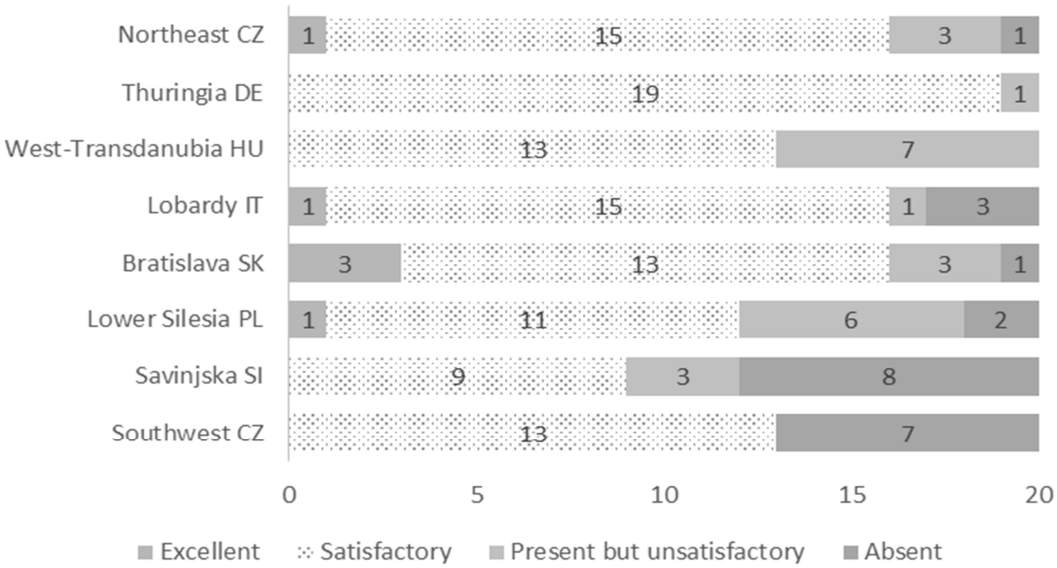

Source: InoPlaCe Comparative Study (2014a). 
According the Figure 1 (InoPlaCe Comparative Study, 2014a) there are just five services delivered in an excellent manner out of all, and three of these are provided in the Bratislava Region. On the contrary, 24 services are delivered in an unsatisfactory way and 22 services are completely absent. Key service "First contact and information point for young innovators" is the best provided service on average and three regions deliver it in an excellent way.

Other services provided in an adequate manner on average are:

- Support in finding investors from industry and enterprises;

- Incubation and networking;

- Business angels and venture capital;

- Support of project development and applications for funds;

- Business start-up.

In contrast, it appears critical to improve delivery performances for:

- Access to young innovators to technological parks and other R\&D premises;

- Public Relations;

- Technology transfer;

- Personalized training for young innovators and their companies;

- Networking conferences.

Public Relations is not just one of the poorest scored services, but also the one present in fewest regions (just 3 out of 8 regions offer it). Support in finding investors from industry and enterprises is the second least provided service 8 out of 20 services are offered in all regions. There is no clear relation between the presence of the service in any region and the delivery performance. Only two regions provide all the services, but not all the services are provided at a satisfactory level. Only 4 services are provided in all regions at a satisfactory level. According (InoPlaCe Comparative Study, 2014a) there are differences among regions that should be highlighted and further analyzed. For example:

- The "visibility" item seems to be rated particularly high in the Southwest (Czech Republic) -even if this doesn't seem to help the number of users of services;

- The affordability and outreach to potential beneficiaries are critical aspects in all regions except Thuringia This feature is very critical in Western Transdanubia;

- The interrelation among services is very critical in all regions, except for the Southwest (Czech Republic).

\subsection{Characteristics of Services}

The table below depict the relation between regions and characteristics of the services. 
Table 3

\section{Services Characteristics in InoPlaCe Partner Regions}

\begin{tabular}{|c|c|c|c|c|c|c|c|c|}
\hline & 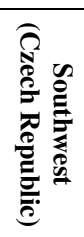 & 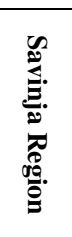 & 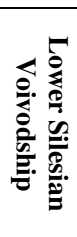 & 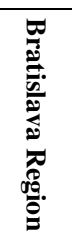 & 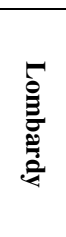 & 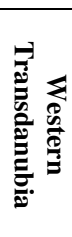 & 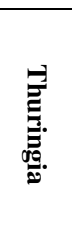 & 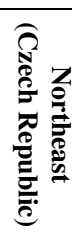 \\
\hline Visibil & 9,08 & 8,33 & 8,27 & 8,14 & 6,66 & 6,60 & 6,89 & 7,88 \\
\hline Availability in space & 5,92 & 5,08 & 4,78 & 4,47 & 5,55 & 5,94 & 6,05 & 5,19 \\
\hline Affordability & 6,54 & 7,64 & 5,98 & 7,06 & 5,72 & 4,02 & 9,50 & 8,20 \\
\hline $\begin{array}{l}\text { Number of users of the service } \\
\text { in the region }\end{array}$ & 3,13 & 4,43 & 4,17 & 6,18 & 6,48 & 3,74 & 7,36 & 4,65 \\
\hline $\begin{array}{l}\text { Practical impact of the service } \\
\text { Interrelation to other key supporting }\end{array}$ & & 6,72 & 7,46 & 7,06 & 6,59 & 5,65 & 6,23 & 7,60 \\
\hline $\begin{array}{l}\text { services } \\
\text { Extent to which the service match } \\
\text { the descrintion in the final list }\end{array}$ & 6,82 & 2,04 & 1,85 & 5,11 & 5,43 & 1,43 & 2,53 & 1,79 \\
\hline & 7,92 & 5,51 & 7,68 & 7,65 & & 7,39 & 6,28 & 7,81 \\
\hline
\end{tabular}

Source: InoPlaCe Comparative Study (2014a).

\section{Conclusions}

In this paper, the key supporting services required by young innovators are listed according to a survey among members of the Regional Innovative Labs established in partner regions established at the beginning of the project. Furthermore, the data presented shows how well the needs of young innovators are currently covered by regional supporting services actors. The study provides a basic comparison of the selected regions and highlights the strengths and weaknesses of such services across the researched regions; thus, the scope for improvements is revealed and opportunities for further actions are identified, be it in the project framework or beyond.

This paper is a valuable data source for young innovators themselves, services providers and regional decision makers who can increase their knowledge of the status quo of the support available for young innovators in the respective regions. Another target group is the broader professional community dealing with innovation support; hence the study is also to be understood as an impetus for enhancement of the support mainly, but not only, for young innovators and an input for the design and implementation of policies and instruments favorable for the development and realization of young innovators' potential.

According to the analysis presented, there are only two regions with a complete set of services and only four regions have a service ranking as excellent in the services' portfolio. A large number of services are reported as present, yet provided in a way not considered satisfactory. However, the largest share of the services is in the category designated as having satisfactory quality. 
It is obvious that the scope for potential improvements is extensive and concerns not only the availability but also the quality of the services. The results of the study presented in this paper can help project partners to identify the gaps and weaknesses in services for young innovators and identify opportunities to draw on the experience and strengths of the others. Within the project the following pilot actions were taken to transfer good practices:

- Southwest CZ adopted PR support from Northeast CZ;

- Savinja SI adopted personalized training for young innovators from Lombardy IT;

- Lower Silesia PL adopted support of project development and applications for funds from Southwest CZ;

- Bratislava SK adopted PR support from Western Transdanubia HU;

- Lombardy IT adopted Creative Hub from Thuringia DE;

- Western Transdanubia adopted support of project development and applications for funds from Bratislava SK;

- Thuringia DE adopted business start-up from Bratislava SK;

- Northeast CZ adopted support in business plan development from Lombardy IT.

Other actions taken within the project and after project closure are described in the InoPlace Transnational Action Plan (InoPlace, 2014c).

\section{References}

BALLON, P. - VAN HOED, M. - SCHUURMAN, D. (2018): The Effectiveness of Involving Users in Digital Innovation: Measuring the Impact of Living Labs. Telematics and Informatics, 35, No. 5, pp. $1201-1214$.

BAUMOL, W. (2004): Education for Innovation: Entrepreneurial Breakthroughs vs Corporate Incremental Improvements. [NBER Working Paper Series.] Cambridge: National Bureau of Economic Research.

BELSO-MARTINEZ, J. - MOLINA-MORALES, F. - MAS-VERDU, F. (2013): Combining Effects of Internal Resources, Entrepreneur Characteristics and KIS on New Firms. Journal of Business Research, 66, No. 10, pp. 2079 - 2089.

BERGVALL-KAREBORN, B. - IHLSTROM ERIKSSON, C. - STAHLBROST, A. - SVENSSON, J. (2007): A Milieu for Innovation - Defining Living Labs. The 2nd ISPIM Innovation Symposium - Stimulating Recovery - The Role of Innovation Management. New York City.

BOBILLO, A. M. - SANZ, J. A. - GAITE, F. T. (2006): Innovation Investment, Competitiveness, and Performance in Industrial Firms. Thunderbird International Business Review, 486, No. 6, pp. $867-890$.

BOND, S. R. - GUCERI, I. (2016): R\&D and Productivity: Evidence from Large UK Establishments with Substantial R\&D Activities. Economics of Innovation and New Technology, 26, No. $1-2$, pp. $108-120$.

BRONZINI, R. - PISELLI, P. (2016): The Impact of R\&D Subsidies on Firm Innovation. Research Policy, 45, No. 2, pp. $442-457$.

BRUNEEL, J. - RATINHO, T. - CLARYSSE, B. - GROEN, A. (2012): The Evolution of Business Incubators: Comparing Demand and Supply of Business Incubation Services across Different Incubator Generations'. Technovation, 32, No. 2, pp. 110 - 121. 
CAIAZZA, R. (2014): Benchmarking of Business Incubators Benchmarking: An International Journal, 21, No. 6, pp. $1062-1069$.

CRESWELL, J. W. - CLARK, V. L. (2017): Designing and Conducting Mixed Methods Research. London: SAGE. ISBN 9781483344379.

DAWSON, B. K. - YOUNG, L. - TU, C. - CHONGYI, F. (2014): Co-innovation in Networks of Resources - A Case Study in the Chinese Exhibition Industry. Industrial Marketing Management, 43, No. 3, pp. $496-503$.

DIVISEKERA, S. - NGUYEN, V. (2018): Determinants of Innovation in Tourism Evidence from Australia. Tourism Management, 67, pp. 157 - 167.

DOLEŽAL, J. - MÁCHAL, P. - LACKO, B. (2012): Projektový management podle IPMA. Praha: Grada Publishing. ISBN 978-80-247-4275-5.

DUMONT, M. (2017): Assessing the Policy Mix of Public Support to Business R\&D. Research Policy, 46, No. 10, pp. 1851 - 1862.

FøLSTAD, A. (2008): Living Labs for Innovation and Development of Information and Communication Technology: A Literature Review. The Electronic Journal for Virtual Organisations and Networks, 10, pp. $100-131$.

GRAY, D. E. (2009): Doing Research in the Real Word. London: SAGE. ISBN 9781526418524.

HALL, B. H. - LOTTI, F. - MAIRESSE, J. (2009): Innovation and Productivity in SMEs: Empirical Evidence for Italy. Small Business Economics, 33, No. 1, pp. 13 - 33.

HENDERSON, R. - CLARK, K. (1990): Architectural Innovation: The Reconfiguration of Existing Product Technologies and the Failure of Established Firms Administrative Science Quarterly, 35, No. 1, pp. $9-30$.

HENDERSON, R. (1993): Underinvestment and Incompetence as Responses to Radical Innovation: Evidence from the Photolithographic Alignment Equipment Industry. RAND J Econ, 24, No. 2, pp. $248-270$.

HENKEL, J. - RøNDE, T. - WAGNER, M. (2015): And the Winner Is - Acquired Entrepreneurship as a Contest Yielding Radical Innovations. Res Policy, 44, No. 2, pp. 295 - 310. DOI: 101016/jrespol201409004.

HOTTENROTT, H. - LOPES-BENTO, C. (2014): R\&D Collaboration and SMEs: The Effectiveness of Targeted Public R\&D Support Schemes. Research Policy, 43, No. 6, pp. 1055 - 1066.

HOWELLS, J. (2006): Intermediation and Role of Intermediaries in Innovation. Research Policy, 35 , No. 5 , pp. $715-728$.

HYYTINEN, A. - PAJARINEN, M. - ROUVINEN, P. (2015): Does Innovativeness Reduce Startup Survival Rates? Journal of Business Venturing, 30, No. 4, pp. $564-581$.

CHO, S-P. - LIM, K. - KWON, G-J. - SUNG, Y-H. (2008): R\&D Investment and Performance in Korea: Korean R\&D Scoreboard 2005. Asian Journal of Technology Innovation, 16, No. 1, pp. $143-160$.

InoPlaCe (2014a): Comparative Study on Key Supporting Services for Young Innovators in Central Europe. Retrieved May 9, 2016. Available at:

<https://dex-ic.com/media/cache/file/68/Comparative-Study_final_23092013.pdf〉.

InoPlaCe (2014b): Good Practice Compendium. Retrieved May 9, 2016. Available at: <https://dex-ic.com/media/cache/file/55/GP-Compendium_Final.pdf $>$.

InoPlace (2014c): Transnational Action Plan. Retrieved May 9, 2016. Available at: $<$ http://dex-ic.com/data/filecache/9d/3.3.4.-InoPlaCe-TAP.docx>.

KAUFMANN, A. - TÖDTLING, F. (2002): How Effective is Innovation Support for SMEs? An Analysis of the Region of Upper Austria Technovation, 22, No. 3, pp. 147 - 159.

LAMB, D. (2012): Establishing and Maintaining Focus in Your Research: Promoting the Use and Effective Implementation of Focus Group Methodology in a 'Real-Life'. Research Study Proceedings of the 11th European Conference on Research Methods, pp. 215 - 221.

LEE, S. - NAM, Y. - LEE, S. - SON, H. (2016): Determinants of ICT innovations: A Crosscountry Empirical Study. Technological Forecasting \& Social Change, 110, pp. $71-77$. 
LERNER, J. (2010): The Future of Public Efforts to Boost Entrepreneurship and Venture Capital Small Business Economics, 35, No. 3, pp. 255 - 264.

LEWIS, D. A. (2002): Does Technology Incubation Work? A Critical Review of the Evidence Athens, OH: National Business Incubation Association.

MAS-TUR, A. - MOYA, V. (2015): Young Innovative Companies (YICs) and Entrepreneurship Policy. Journal of Business Research, 68, No. 7, pp. 1432 - 1435.

MAZZA, R. - BERRE, A. (2007): 'Focus group Methodology for Evaluating Information Visualization Techniques and Tools. 11th International Conference on Information Visualization (IV 2007), Zurich, Switzerland, pp. $74-78$.

MERGEL, I. (2015): Opening Government Designing Open Innovation Processes to Collaborate with External Problem Solvers. Social Science Computer Review, 33, No. 5, pp. 599 - 612.

MIRIJAMDOTTER, A. - SOMERVILLE, M. M. - HOLST, M. (2006): An Interactive and Iterative Evaluation Approach for Creating Collaborative Learning Environments. The Electronic Journal of Information Systems Evaluation (EJISE), 9, No. 2, pp. 83 - 92.

NYSTROM, A. G. - LEMINEN, S. - WESTERLUND, M. - KORTELAINEN, M. (2014): Actor Roles and $€$ Role Patterns Influencing Innovation in Living Labs. Industrial Marketing Management, 43, No. 3, pp. $483-495$.

PAPAZOGLOU, M. - SPANNOS, Y. (2018): Bridging Distant Technological Domains: A Longitudinal Study of the Determinants of Breadth of Innovation Diffusion. Research Policy, 47, No. 9, pp. $1713-1728$.

PITRA, Z. (2006): Management inovačních aktivit Praha: Professional Publishing. ISBN 9788086946108.

PROKOP, V. - STEJSKAL, J. - KUVIKOVA, H. (2017): The Different Drivers of Innovation Activities in European Countries: A Comparative Study of Czech, Slovak, and Hungarian Manufacturing Firms. Ekonomický časopis/Journal of Economics, 65, No. 1, pp. 31 - 45.

PROTOGEROU, A. - CALOGHIROU, Y. - VONORTAS, N. (2017): Determinants of Young Firms' Innovative Performance: Empirical Evidence from Europe. Research Policy, 46, No. 7 , pp. $1312-1326$.

RAUTER, R. - GLOBOCNIK, D. - PERL-VORBACH, E. - BAUMGARTNER, R. (2018): Open Innovation and Its Effects on Economic and Sustainability Innovation Performance. Journal of Innovation \& Knowledge, 4, No. 4, pp. $226-233$.

ROIG-TIERNO, N. - ALCÁZAR, J. - RIBEIRO-NAVARRETE, S. (2015): Use of Infrastructures to Support Innovative Entrepreneurship and Business Growth. Journal of Business Research, 68, No. 11, pp. $2290-2294$.

SCHAFFERS, H. - TURKAMA, P. (2012): Living Labs for Cross-border Systemic Innovation. Technology Innovation Management Review, September, pp. 25 - 30.

SCHUMPETER, J. A. (1934): The Theory of Economic Development. Cambridge, MA: Harvard University Press.

STANEK, R. - KVASNICKA, M. - KRCAL, O. (2018): Do R\&D Subsidies Support Innovation or Imitation? Evidence from Four EU Countries. Ekonomický časopis/Journal of Economics, 66, No. 9, pp. $909-924$.

STAMM, von B. (2005): Managing Innovation, Design and Creativity. New York: J Wiley.

STERNBERG, R. (2014): Success Factors of University Spin Offs: Regional Government Support Programs versus Regional Environment. Technovation, 34, No. 3, pp. 137 - 148.

TAVASSOLI, S. (2015): Innovation Determinants over Industry Life Cycle. Technological Forecasting \& Social Change, 91, pp. $18-32$.

Van WEEL, M. - Van RIJNSOEVER, F. - NAUTA, F. (2017): You Can't Always Get What You Want: How Entrepreneur's Perceived Resource Needs Affect the Incubator's Assertiveness. Technovation, 59, pp. $18-33$.

VEUGELERS, R. - SCHNEIDER, C. (2018): Which IP Strategies Do Young Highly Innovative Firms Choose? Small Business Economics, 50, No. 4, pp. 113 - 129.

YUSUF, J. (2010): Meeting Entrepreneurs' Support Needs: Are Assistance Programs Effective? Journal of Small Business and Enterprise Development, 17, No. 2, pp. 294 - 307. 